\title{
Factors Affecting Students' Acceptance of e- Learning System in Higher Education
}

\author{
Nurhafizah Ahmad ${ }^{1 *}$, Norazah Umar' ${ }^{2}$, Rozita Kadar ${ }^{3}$, Jamal Othman ${ }^{4}$ \\ ${ }^{1,2,3,4}$ Department of Computer and Mathematical Sciences, \\ Universiti Teknologi MARA Cawangan Pulau Pinang, Malaysia \\ Corresponding author:*nurha9129@uitm.edu.my \\ Received Date: 10 August 2020 \\ Accepted Date: 7 October 2020
}

\begin{abstract}
e-Learning has become the most important supporting tool offering independent learning style among students. The main idea of this paper is to dismantle and analyse factors that influence the acceptance of e-Learning among students in higher education. An online questionnaire link was distributed to a sample comprising 123 respondents. Significant relationships and strength of relationship were observed between the e-Learning acceptance, quality, e-Learning self-efficacy, enjoyment, accessibility, and computer playfulness. The findings showed that all factors were positively correlated to the e-Learning system except the enjoyment of e-learning that did not affect the acceptance of e-learning. Conclusively, all factors stated were considered the main criteria in designing effective e-learning system. Future works such as embedding and integrating multimedia elements in the e-learning system will be additional attraction to learners and instructors for the effective learning style.
\end{abstract}

Keywords : e-learning, LMS, TAM, MOOC

\section{INTRODUCTION}

Traditionally, the delivery of instructions in most public universities depends on the classroom, which the lecturer delivers the lecture while the students listen and take notes. The communication between the lecturer and the learners has been identified as an important learning component in delivery platform (Harandi, 2015). The challenge of traditional education approaches is that the computer technology propels attractive innovation specifically in the delivery of instructions to learners (Keller and Suzuki, 2004).

Modernisation of education is extensively affected by the Internet, information and communications technologies (Sangrà, Vlachopoulos, and Cabrera, 2012). E-learning is defined as adopting the new technology devices and variety of electronic media as supporting tools in teaching and learning to improve understanding of knowledge through training, communications and active interactions in virtual environment (Krishnan and Hussin, 2017). When the learning environments are facilitated with technologies such as the Internet, hardware and Learning Management System (LMS) software, positive impact can be seen in the learning quality and investment of cost benefits analysis (Bates, 1997).

E-learning has been recognised as an important learning and teaching supporting tool in the higher education all over the world (Mohammad, 2015). E-learning provides a very comprehensive atmospheres among learners for actively participating in the academic activities (Al-Rahmi et al., 2018). E-learning offers extensive benefits for bridging the gaps between the physical and virtual presence of the 
instructors. It shows the improvement of learning curve and positive impact among weak students to understand the fundamental knowledge of the subject matters. Furthermore, it has been revealed that the undergraduate students with e-learning education exposure and experience are more intrinsically motivated and matured than those with traditional education systems (Rovai et al., 2007).

In Malaysia, e-Learning has been acknowledged to widen its usage to full-timers students, which previously benefited by the part-timer students only. One of the e-learning applications is the Massive Open Online Courses (MOOCs), which is an online course accessible by unlimited users and open access through the web. The flexible learning or the distance learning program offered by the public and private universities should provide very established and reliable e-learning platform in providing educational material for learners. Otherwise, the leaners would feel demotivated and negative rapport imposed to the image of the universities.

Universiti Teknologi MARA (UiTM) has introduced the iLearn portal, which focuses on the advancement of modern communication technologies to ensure the consistency and reliability of web-based instruction compared to conventional teaching methods. Besides iLearn, MOOC and uFuture also were used widely as e-learning platform for the students. Hence, this paper concentrates on the students' acceptance of eLearning approaches in Universiti Teknologi MARA, Penang branch using Technology Acceptance Model (TAM) framework (Holden and Rada, 2011). The top management of Academic Affairs Department and the policy makers are aware on the enhancement of e-learning technologies that should be concentrated and improvised based on the students' perspectives and expectations so that the improvements are aligned and paralleled with university's objectives and ministry visions to produce competitive and world class graduates as the ultimate goal.

Generally, the organisation of this paper starts with the discussion of related works. Then, the following part presents the discussion of the methodology and continues to findings and further discussion of data analysis. Finally, the conclusion and future works of the research are elaborated at the end of this paper.

\section{RELATED WORK}

This section discusses the internal factors suggested in previous works which are: Unified Theory of Acceptance and Use of Technology (UTAUT); Technology Acceptance Model (TAM); and Structural equation model-neural network (SEM-NN) model that influence the students' acceptance of the elearning and the summary of the previous works based on the analyses of external factors as shown in Table 1.

In predicting a student's intention to use E-learning, the Unified Theory of Acceptance and Use of Technology (UTAUT) model have been used by Salloum (2019) to obtain the results. The result showed that users can have enormous benefits from E-learning system. The findings revealed that all internal factors of behavioural intention to use E- learning system were reportedly found as the social influence, performance expectancy and facilitating conditions of learning. Hanif et al. (2018) proposed a study to develop and present a model of e-learning system adoption based on the technology-acceptance model (TAM). The study examined several external variables for the present-world students brought up as digital learners and have higher levels of computer literacy and experience. The work explored and developed relationships between the perceived usefulness (PU) and perceived ease of use (PEOU) of the e-learning system. Results indicated that subjective norm, perception of external control, system 
accessibility, enjoyment and result demonstrability have a significant positive influence on perceived usefulness and on perceived ease of use of the e-learning system.

Sharma et al. (2017) attempted to develop a causal and predictive statistical model for predicting instructor e-learning acceptance using The Structural Equation Model (SEM) and Neural Network (NN). The results demonstrated that system quality, personal innovativeness, service quality and technology experience have a statistically significant influence on continuous usage of e-learning by instructors. Indahyanti (2015) used the Technology Acceptance Model (TAM) to measure factors inluencing students' acceptance of Learning Management System (LMS) using TAM model. The results showed that the TAM was valid, reliable and substantially acceptable based on the results of data evaluation.

Table 1 Summary of the Internal Factors on Technology Acceptance

\begin{tabular}{|c|c|c|c|c|}
\hline \multirow[b]{2}{*}{ Author(s) } & \multicolumn{3}{|c|}{ Model Used } & \multirow[b]{2}{*}{ Internal Factors } \\
\hline & 占 & $\sum_{\in}$ & $\sum_{\substack{\text { Z⿱ } \\
\text { Z }}}^{Z}$ & \\
\hline Salloum (2019) & $\sqrt{ }$ & & & $\begin{array}{l}\text { Performance expectancy, effort expectancy, social influence } \\
\text { and facilitating conditions }\end{array}$ \\
\hline Hanif et al. (2018) & & $\sqrt{ }$ & & $\begin{array}{l}\text { Result demonstrability, Subjective Norm, Enjoyment, Self- } \\
\text { efficacy, Perception of External Control, System Accessibility. }\end{array}$ \\
\hline Sharma et al. (2017) & & & $\sqrt{ }$ & $\begin{array}{l}\text { technology experience, personal innovativeness, system } \\
\text { quality, information quality, and service quality }\end{array}$ \\
\hline Indahyanti (2015) & & $\sqrt{ }$ & & $\begin{array}{l}\text { perceived usefulness, perceived ease of use, and attitudes } \\
\text { towards to use, affecting the intention to use }\end{array}$ \\
\hline Andana \& Elvina (2015) & $\sqrt{ }$ & & & $\begin{array}{l}\text { e-learning motivation, facilitating conditions, behavioral } \\
\text { intention. }\end{array}$ \\
\hline Al-Rahmi et al. (2015) & & $\sqrt{ }$ & & $\begin{array}{l}\text { self-efficacy, learner interface, learning community, students' } \\
\text { satisfaction, perceived usefulness, intention to use e-learning, } \\
\text { e-learning effectiveness }\end{array}$ \\
\hline
\end{tabular}

Unified Theory of Acceptance and Use of Technology (UTAUT); Technology Acceptance Model (TAM); Structural equation model-neural network (SEM-NN)

The work by Andana \& Elvina (2015) to study the implementation of ClassCraft E-Learning tool in the university was based on the model of the Unified Theory of Acceptance and Use of Technology (UTAUT). Findings presented that the significant factors affecting users to receive and use the Classcraft at the university were E-Learning Motivation and Behavioural Intention. This means that user's interest in Classcraft is important as it affects the users in implementing Classcraft; so, these factors should be maintained. Al-Rahmi et al. (2015) proposed a work on evaluating the e-learning effectiveness in Universiti Teknologi Malaysia (UTM). The results showed that e-learning use was positively and significantly related to students' satisfaction, in which usefulness impacted the intention to use in turn affected e-learning effectiveness. Apart from that, the findings showed that e-learning facilitated academic experience of the participants, making them to have the intention to use e-learning. 
From this review, we found that the Technology Acceptance Model (TAM) and the Unified Theory of Acceptance and Use of Technology (UTAUT) are the well-known technology acceptance models. These models are used to predict technology usage by looking at the variables that will influence technology acceptance. The questions that both models focus which are: Is the technology useful for me? and Is the technology easy to use? UTAUT model adds two further questions to this list which are: Does my social environment want me to use the technology? and Do I have the necessary technical and organizational infrastructure to use the technology? Both have several similarities that aim to understand better why users accept or reject a given technology, and how user acceptance can be improved through technology design (see Table 2).

Table 2 Similarity of variables in TAM and UTAUT

\begin{tabular}{|c|c|c|c|}
\hline \multirow{2}{*}{ No. } & \multicolumn{2}{|c|}{ Similarity Variable } & \multirow{2}{*}{ Descriptions } \\
\hline & TAM & UTAUT & \\
\hline S1 & $\begin{array}{l}\text { Perceived } \\
\text { Usefulness }\end{array}$ & $\begin{array}{l}\text { Performance } \\
\text { Expectancy }\end{array}$ & $\begin{array}{l}\text { The expectation of a user that the system will be useful for the } \\
\text { job. }\end{array}$ \\
\hline S2 & $\begin{array}{l}\text { Perceived Ease } \\
\text { of Use }\end{array}$ & $\begin{array}{l}\text { Effort } \\
\text { Expectancy }\end{array}$ & The expectation that the system is user friendly and easy to use. \\
\hline S3 & $\begin{array}{l}\text { Attitude } \\
\text { towards using }\end{array}$ & Social Influence & $\begin{array}{l}\text { The degree to which a user perceives that important others } \\
\text { believe he or she should use the new system. }\end{array}$ \\
\hline S4 & Use & $\begin{array}{l}\text { Facilitating } \\
\text { Conditions }\end{array}$ & $\begin{array}{l}\text { The degree to which a user believes that an organizational and } \\
\text { technical infrastructure exists to support system use. }\end{array}$ \\
\hline S5 & $\begin{array}{l}\text { Behavioural } \\
\text { Intention to Use }\end{array}$ & $\begin{array}{l}\text { Behavioural } \\
\text { Intention }\end{array}$ & $\begin{array}{l}\text { The motivation or willingness to exert effort to perform the } \\
\text { target behavior. }\end{array}$ \\
\hline
\end{tabular}

* S - Similarity

\section{DATA COLLECTION METHODOLOGY}

The questionnaire was designed based on the instruments used in previous studies with some modifications made to suit the objective of the study. In Table 3 shows the summary of the variables that used in this study. This table listed the factors dan the descriptions of the factors as well as the similarity variables resulted from the integration of TAM and UTAUT.

The questionnaire consisted of two parts. The first part involved questions on demographic profile including age, gender, level of education, field, faculty and some general questions pertaining the elearning system. The second part comprised five factors that contribute to the acceptance of e-learning system including quality, e-learning self-efficacy, enjoyment, accessibility, and computer playfulness. The questionnaire was rated using a five -point Likert scale, which were strongly agree (5), agree (4), neutral (3), disagree (2) and strongly disagree (1). 123 valid responses were obtained from the survey and IBM SPSS (Version-20) were used to analyse the collected data.

The data for the analysis was gathered through a survey questionnaire distributed to the students from a few faculties in Universiti Teknologi Mara, Penang Branch. The cluster sampling technique was used because of the multiple linear regression analysis used in the study (Field, 2005) and also to relief the 
generalisation of outcomes to the target population. The link for the survey was sent to the respondents via WhatsApp application, which required them to give information about their experiences with using elearning.

Table 3 Summary of the Internal Factors on Technology Acceptance

\begin{tabular}{|c|c|c|}
\hline Factor & Descriptions & *Similarity (S) \\
\hline $\begin{array}{l}\text { e-Learning } \\
\text { System } \\
\text { Acceptance }\end{array}$ & $\begin{array}{l}\text { Look on how far the e-learning system provides easiness, } \\
\text { usefulness, attractive interaction, and comprehensive learning } \\
\text { environment for the learners to understand the subject matters. } \\
\text { Furthermore, the system acceptance measures additional attributes } \\
\text { such as frequency of usage, dependency degree on the system and } \\
\text { possibility to recommend or promotes system positive impact to } \\
\text { others. }\end{array}$ & $\mathrm{S} 1, \mathrm{~S} 2$ \\
\hline Quality & $\begin{array}{l}\text { This variable focuses on the valuable, relevancy and arrangement } \\
\text { of the contents in the e-learning systems, impact of the features and } \\
\text { appearances, respond time, real-time data and information which } \\
\text { affects the confidence and trust level of the learners. }\end{array}$ & S4 \\
\hline $\begin{array}{l}\text { e-Learning } \\
\text { Self Efficacy }\end{array}$ & $\begin{array}{l}\text { Beliefs in students' capabilities in accomplishing activities in e- } \\
\text { learning and improving satisfaction. Student also confident and } \\
\text { have a good skill in using the e-learning system without any helps. }\end{array}$ & S5 \\
\hline Enjoyment & $\begin{array}{l}\text { A student's subjective feeling of joy, pleasure and positive } \\
\text { experience in using e-learning system. Enjoyment act as a catalyst } \\
\text { to encourage students learning initiative using e-learning system. }\end{array}$ & S3 \\
\hline Accessibility & $\begin{array}{l}\text { Accessibility implies that the system can be used conveniently and } \\
\text { frequently. Supporting facilities provided by organizational play } \\
\text { an important role in an individual's decision to use the system and } \\
\text { thus provide a platform in communication among users. }\end{array}$ & S4 \\
\hline $\begin{array}{l}\text { Computer } \\
\text { Playfulness }\end{array}$ & $\begin{array}{l}\text { The expected enjoyment, creativity and exploration gain from the } \\
\text { used of the system. The activities of using the system can help users } \\
\text { to improve their imagination. }\end{array}$ & $\mathrm{S} 3$ \\
\hline
\end{tabular}

*Similarity (S) variable based on the integration of TAM and UTAUT (refer Table 2)

\section{DATA ANALYSIS}

\section{Reliability Test}

The reliability of this study was tested using Cronbach's Alpha since the questionnaire was developed using the multiple Likert scale. Cronbach's Alpha is a reliability test conducted in SPSS to measure the internal consistency and determine the reliability of the scale. It measures how closely related a set of items are as a group. According to Bolarinwa (2015), reliability test is well-defined as the level to which a questionnaire, test, observation, or any measurement practice create the same results on frequent trials. Table 4 below shows the value of Cronbach's Alpha ranging from zero to one with 0 showing complete unreliability while 1 showing a perfect reliability. 
Table 4: Range of Cronbach's Alpha

\begin{tabular}{ccc}
\hline No & Coefficient of Cronbach's Alpha & Reliability Level \\
\hline 1 & More than 0.90 & Excellent \\
2 & $0.80-0.89$ & Good \\
3 & $0.70-0.79$ & Acceptable \\
4 & $0.60-0.69$ & Questionable \\
5 & $0.50-0.59$ & Poor \\
6 & Less than 0.50 & Unacceptable \\
\hline
\end{tabular}

Source: Adopted from George and Mallery (2003).

\section{Correlation}

Correlation analysis is generally used to measure the strength of relationship between dependent and independent variables (Sharma et al., 2017). If the correlation value is non-existent $(r=0)$, it means that there is no relationship between the variable, whereas if the correlation value with 1, it indicates a perfect relationship between dependent and independent variables. The correlation coefficient value may be interpreted from negligible to high positive/negative as shown in Table 5.

Table 5: Size of correlation coefficient and its interpretation

\begin{tabular}{cl}
\hline \multicolumn{1}{c}{ Size of Correlation } & \multicolumn{1}{c}{ Interpretation } \\
\hline 0.90 to $1.00(-0.90$ to -1.00$)$ & Very high positive (negative) correlation \\
0.70 to $0.90(-0.70$ to -0.90$)$ & High positive (negative) correlation \\
0.50 to $0.70(-0.50$ to -0.70$)$ & Moderate positive (negative) correlation \\
0.30 to $0.50(-0.30$ to -0.50$)$ & Low positive (negative) correlation \\
0.00 to $0.30(0.00$ to -0.30$)$ & Negligible correlation \\
\hline
\end{tabular}

(Source: Hinkle et al., 2003)

\section{Multiple Linear Regression}

In this study, multiple linear regression analysis was used to determine the factors (quality, e-learning self-efficacy, enjoyment, accessibility, computer playfulness) affecting students' acceptance of e-learning system in higher education. Regression analysis studies the situation where a dependent variable (DV) is concurrently influenced by a number of independent variables. The regression model was evaluated based on R Square, Adjusted R Square, Beta (B) and its corresponding indicator ( $p$ value). R Square refers to the percentage of variance of dependent variable that can be explained by the independent variables. A high R Square means that there is a strong relationship between the variables.

The equation of regression models is as shown in equation (Eq. 1) below:

$$
\left.y=\beta_{0}+\beta_{1} x_{1}+\beta_{2} x_{2}+\beta_{3} x_{3}+\beta_{4} x_{4}+\beta_{5} x_{5}--------------- \text { (Eq. } 1\right)
$$

where:

$\mathrm{x}_{1}=$ Quality $\mathrm{x}_{2}=$ e-learning self-efficacy, $\mathrm{x}_{3}=$ Enjoyment, $\mathrm{x}_{4}=$ Accessibility, $\mathrm{x}_{5}=$ Computer Playfulness and $y=$ e-learning system acceptance (DV). 


\section{RESULTS AND DISCUSSION}

\section{Reliability Analysis}

Table 6 below provides the summary of Cronbach's Alpha value for all variables. The result revealed the value of more than 0.78 for all variables, reflecting high reliability and validity of all variables. George \& Mallery (2003), stated that an alpha of 0.80 is probably a reasonable goal. Besides, the values of Cronbach's Alpha confirmed that there was a consistency of measurement items for all variables.

Table 6: Summary of Cronbach's Alpha

\begin{tabular}{lccc}
\hline Variable & No of items & Cronbach's Alpha & Result \\
\hline e-learning system acceptance (DV) & 13 & 0.956 & Excellent \\
Quality & 9 & 0.925 & Excellent \\
e-learning self-efficacy & 3 & 0.779 & Acceptable \\
Enjoyment & 3 & 0.850 & Good \\
Accessibility & 3 & 0.852 & Good \\
Computer Playfulness & 3 & 0.900 & Excellent \\
\hline
\end{tabular}

\section{Correlation Analysis}

The summary of Pearson correlation between dependent (e-learning system acceptance) and independent variables (quality, e-learning self-efficacy, enjoyment, accessibility, computer playfulness) is shown in Table 7 . With $\mathrm{p}$ value less than 0.05 , it shows all the variables were significantly correlated with the elearning system acceptance. Based on the findings below, there was a high positive relationship between quality and e-learning system acceptance. The coefficient of Pearson correlation of quality and e-learning system acceptance was 0.855 . Similar finding was observed for e-learning self-efficacy, enjoyment, accessibility and computer playfulness, which also showed a high positive correlation with coefficient of Pearson correlation of $0.766,0.732,0.740$ and 0.736 , respectively. This means that all the variables are the very strong factors affecting students' acceptance of e-learning system. In line with this, the result by Ahn et al. (2007) also indicated that playfulness has a significant positive effect on individual attitude and behavioural intention to use online retailing. This finding is in agreement with that by Fianu et al. (2018) showing that computer self-efficacy was found to have a significant positive effect on MOOC Usage Intention. Additionally, Pellas (2014) suggested that students with higher e-learning self-efficacy are more likely to use e-learning.

Table 7: Summary of Pearson Correlation

\begin{tabular}{llccccc}
\hline & Quality & $\begin{array}{c}\text { e-learning } \\
\text { self-efficacy }\end{array}$ & Enjoyment & Accessibility & $\begin{array}{c}\text { Computer } \\
\text { Playfulness }\end{array}$ \\
\hline $\begin{array}{l}\text { e-learning } \\
\text { system }\end{array}$ & Pearson Correlation & 0.855 & 0.766 & 0.732 & 0.740 & 0.736 \\
acceptance & p-value & 0.000 & 0.000 & 0.000 & 0.000 & 0.000 \\
\hline
\end{tabular}




\section{Multiple Linear Regression}

The coefficient of regression is as shown in Table 5. The variable with the p-value less than 0.05 showed that the factor has significantly affected students' acceptance of e-learning system. Based on the finding, it was found that quality ( $p$-value $=0.000$ ) had a significant effect on e-learning system acceptance. This is consistent with that of a previous study, which confirmed that information quality and system quality had some influence on the intention to use the ClassStart (Thongsri, Shen, and Bao, 2019). Moreover, Sharma et al. (2017) found that the main issue affecting the acceptance of learners was system quality (Ahn, Ryu, and Han, 2007; Fianu et al. 2018; Wang, Wu, and Wang, 2009). Therefore, a successful e-learning system must have a high functionality with exceptional service quality.

Besides, the finding of this study also showed that e-learning self-efficacy (p-value $=0.003$ ) had a significant effect on e-learning system acceptance. This provided the support for studies conducted by Agarwal \& Prasad (1999), Chang \& Tung (2008) and Fianu et al. (2018) which found that computer selfefficacy was critical for students' behavioural intentions to use the online learning course websites. These mean that those with a higher self-efficacy will have greater confidence in their ability to use e-learning software and hardware devices.

Result from Table 8 shows that accessibility ( $p$-value $=0.018$ ) had a significant effect on e-learning system acceptance. These results match those observed in earlier studies such as that by S. A. S. Salloum \& Shaalan (2018) which confirmed that accessibility has a significant influence on students' perceived ease of use and perceived usefulness of e-learning systems. In addition, Attis (2014) found a significant impact of accessibility on perceived ease of use of e-learning system.

Table 8: Regression Analysis

\begin{tabular}{lccccc}
\hline \multirow{2}{*}{ Model } & \multicolumn{2}{c}{$\begin{array}{c}\text { Unstandardized } \\
\text { Coefficients }\end{array}$} & $\begin{array}{c}\text { Standardized } \\
\text { Coefficients }\end{array}$ & t & p-value \\
\cline { 2 - 4 } & $\mathbf{B}$ & Std. Error & Beta & & \\
\hline (Constant) & 0.142 & 0.168 & & 0.846 & 0.399 \\
Quality & 0.509 & 0.088 & 0.450 & 5.816 & 0.000 \\
e-learning self-efficacy & 0.210 & 0.068 & 0.209 & 3.084 & 0.003 \\
Enjoyment & 0.041 & 0.063 & 0.044 & 0.641 & 0.523 \\
Accessibility & 0.148 & 0.062 & 0.152 & 2.397 & 0.018 \\
Computer Playfulness & 0.144 & 0.058 & 0.155 & 2.490 & 0.014 \\
\hline
\end{tabular}

Furthermore, computer playfulness ( $\mathrm{p}$-value $=0.014$ ) had a significant effect on e-learning system acceptance. This finding is in line with the previous study done by S. A. S. Salloum \& Shaalan (2018) studying the factors that affect e-learning system acceptance in the United Arab of Emirates (UAE). The study indicated that system quality, computer self-efficacy and computer playfulness have a significant impact on students' perceived ease of use of e-learning (Fianu et al. 2018; Wang, Wu, and Wang, 2009). 
However, enjoyment ( $p$ value=0.523) had no significant effect on students' acceptance of e-learning system, which is consistent with the result obtained by Sánchez-Franco et al. (2009) who found that the enjoyment of e-learning did not affect the intention to use e-learning among Mediterranean educators.

Table 9 displays the results of $\mathrm{R}$ square. The model was seen significant with an $\mathrm{R}$ square value of 0.803 , indicating that $80.3 \%$ of the total variation of e-Learning system acceptance can be explained by quality, e-learning self-efficacy, accessibility and computer playfulness.

Table 9: Model Summary

\begin{tabular}{ccccc}
\hline Model & R & R Square & $\begin{array}{c}\text { Adjusted R } \\
\text { Square }\end{array}$ & $\begin{array}{c}\text { Std. Error of } \\
\text { the Estimate }\end{array}$ \\
\hline 1 & 0.895 & 0.803 & 0.795 & 0.34358 \\
\hline
\end{tabular}

\section{CONCLUSION AND FURTHER WORKS}

Based on the findings and analysis, the results have significantly and logically showed that factors namely system quality, e-learning system acceptance, e-learning self-efficacy, enjoyment, accessibility and computer playfulness contributed to the students' acceptance of e-learning system. Conclusively, the findings portrayed that most of the developers designing an e-learning system or any Learning Management System (LMS) consider all factors mentioned in this study.

Relatively, the developer should embed other contributing factors that have a high impact on the usage of e-learning systems, which are the audio and visual aid, animation and video elements, so that the learners are fully engaged, attracted and able to absorb the knowledge of the learning content. Ability of interactivity element in an e-learning system with the learners is an additional crucial feature that can encourage the learners to observe the effectiveness of learning curve. Element of rapid interactive response should also be considered by the developer for instance in answering the quizzes from the elearning system where the analysis results can be generated immediately.

Video is an important element in helping students obtain information compared to text-based or imagebased. Video is a powerful tool which provide multi-sensory learning environment that may improve learners' ability to sustain their information or knowledge (Syed, 2001). The use of videos as a teaching and learning material in e-learning has a positive impact to learners. This approach is very important especially in learning programming courses. In addition, the role of persuasive technology in determining the effectiveness of e-learning development is also important. Persuasive technology adaptations are seen to be successful in changing students' attitudes or behaviors towards more positive ones. Thus, our proposed work is to develop an e-content in a form of video that fulfil the ten principles of persuasive technology.

For future works or data analysis frameworks, it is recommended that the response is obtained from the instructors instead of the learners. The survey should encompass the comparison analysis between the instructors' and learners' perspectives whether both results are correlated or significant to each other. Besides, the respondents should be diversified from different modes of study (eg: distance learning 
programme), universities (eg: private universities and colleges), level of studies (eg: diversified from certificate until professional programme) and geographical locations so that the analysis will be more comprehensive and collaborative.

E-learning has grown rapidly, and comprehensive plans are needed to make it available to everyone. Elearning helps learners to grow with better aptitude. Research has proven that e-learning can reduce the learning time. This statement is aligned with other researchers (Ani and Ahiauzu, 2008; Thejeswar and Thenmozhi, 2015) stating that learning time can be reduced by $25 \%$ to $60 \%$ using e-learning compared to classroom-based instructions. Nevertheless, the commitment of the students to study online is the biggest challenge since only self-disciplined and self-motivated learners will be succeed. Relaxed and passion in learning will help learners to understand effectively in the learning process, as supported by Richardson \& Newby (2006). Conclusively, the findings from this study will give ideas specifically to the developers for improving e-Learning systems, encourage the instructors to shift their teaching paradigms to learnercentred education and ultimately promote the students' learning curve through independent learning mode.

\section{REFERENCES}

Agarwal, R., \& Prasad, J. (1999). Are individual differences germane to the acceptance of new information technologies? Decision Sciences, 30(2), 361-391.

Ahn, T., Ryu, S., \& Han, I. (2007). The impact of Web quality and playfulness on user acceptance of online retailing. 44, 263-275. https://doi.org/10.1016/j.im.2006.12.008

Al-Rahmi, W. M., Alias, N., Othman, M. S., Alzahrani, A. I., Alfarraj, O., Saged, A. A., \& Rahman, N. S. A. (2018). Use of e-learning by University students in Malaysian higher educational institutions: A case in Universiti Teknologi Malaysia. IEEE Access, 6, 14268-14276.

Al-rahmi, W. M., Othman, M. S., \& Yusuf, L. M. (2015). The Effectiveness of Using E-Learning in Malaysian Higher Education: A Case Study Universiti Teknologi Malaysia. (November). https://doi.org/10.5901/mjss.2015.v6n5s2p625

Andana, D., \& Elvina, H. (2015). Analysis of Factors Affecting User Acceptance of the Implementation of ClassCraft E- Learning : Case Studies Faculty of Information Technology of Tarumanagara University. 73-78.

Ani, O. E., \& Ahiauzu, B. (2008). Towards effective development of electronic information resources in Nigerian university libraries. Library Management.

Attis, J. (2014). An investigation of the variables that predict teacher e-learning acceptance.

Bates, T. (1997). Restructuring the university for technological change. Murdoch University.

Bolarinwa, O. A. (2015). Principles and methods of validity and reliability testing of questionnaires used in social and health science researches. Nigerian Postgraduate Medical Journal, 22(4), 195.

Chang, S., \& Tung, F. (2008). An empirical investigation of students' behavioural intentions to use the online learning course websites. British Journal of Educational Technology, 39(1), 71-83.

Fianu, E., Blewett, C., Ampong, G., \& Ofori, K. (2018). Factors Affecting MOOC Usage by Students in Selected Ghanaian Universities. Education Sciences, 8(2), 70. 
Field, A. P. (2005). Discovering statistics using SPSS:(and sex, drugs and rock'n'roll). London.

George, D., \& Mallery, M. (2003). Using SPSS for Windows step by step: a simple guide and reference.

Hanif, A., Jamal, F. Q., \& Imran, M. (2018). Extending the Technology Acceptance Model for Use of eLearning Systems by Digital Learners. IEEE Access, PP(c), 1. https://doi.org/10.1109/ACCESS.2018.2881384

Harandi, S. R. (2015). Effects of e-learning on Students' Motivation. Procedia-Social and Behavioral Sciences, 181, 423-430.

Hinkle, D. E., Wiersma, W., \& Jurs, S. G. (2003). Applied statistics for the behavioral sciences (Vol. 663). Houghton Mifflin College Division.

Holden, H., \& Rada, R. (2011). Understanding the influence of perceived usability and technology selfefficacy on teachers' technology acceptance. Journal of Research on Technology in Education, 43(4), 343-367.

Indahyanti, U. (2015). Jurnal Teknologi Full paper Applying the Technology Acceptance Model to Measure the Learning Management System Acceptance by Students of Politeknik Sakti Surabaya. 4, $127-131$.

Keller, J., \& Suzuki, K. (2004). Learner motivation and e-learning design: A multinationally validated process. Journal of Educational Media, 29(3), 229-239.

Krishnan, K. S. T., \& Hussin, H. (2017). E-learning readiness on Bumiputera SME's intention for adoption of online entrepreneurship training in Malaysia. Management, 7(1), 35-39.

Mohammadi, H. (2015). Investigating users' perspectives on e-learning: An integration of TAM and IS success model. Computers in Human Behavior, 45, 359-374.

Pellas, N. (2014). The influence of computer self-efficacy, metacognitive self-regulation and self-esteem on student engagement in online learning programs: Evidence from the virtual world of Second Life. Computers in Human Behavior, 35, 157-170.

Richardson, J. C., \& Newby, T. (2006). The role of students' cognitive engagement in online learning. American Journal of Distance Education, 20(1), 23-37.

Rovai, A., Ponton, M., Wighting, M., \& Baker, J. (2007). A comparative analysis of student motivation in traditional classroom and e-learning courses. International Journal on E-Learning, 6(3), 413-432.

Salloum, S. A. (2019). Factors Affecting Students 'Acceptance of E-Learning System in Higher Education Using UTAUT and Structural Equation Modeling Approaches (Vol. 2). https://doi.org/10.1007/978-3-319-99010-1

Salloum, S. A. S., \& Shaalan, K. (2018). Investigating students' acceptance of E-learning system in Higher Educational Environments in the UAE: Applying the Extended Technology Acceptance Model (TAM). The British University in Dubai.

Sánchez-Franco, M. J., Martínez-López, F. J., \& Martín-Velicia, F. A. (2009). Exploring the impact of individualism and uncertainty avoidance in Web-based electronic learning: An empirical analysis in European higher education. Computers \& Education, 52(3), 588-598.

Sangrà, A., Vlachopoulos, D., \& Cabrera, N. (2012). Building an inclusive definition of e-learning: An 
approach to the conceptual framework. The International Review of Research in Open and Distributed Learning, 13(2), 145-159.

Sharma, S. K., Gaur, A., \& Saddikuti, V. (2017). Structural equation model ( SEM ) -neural network ( NN ) model for predicting quality determinants of e-learning management systems. Behaviour \& Information Technology, O(0), 1-14. https://doi.org/10.1080/0144929X.2017.1340973

Thejeswar, E. P., \& Thenmozhi, M. S. (2015). Educational research-iPad system vs textbook system. Research Journal of Pharmacy and Technology, 8(8), 1158-1160.

Thongsri, N., Shen, L., \& Bao, Y. (2019). Investigating factors affecting learner's perception toward online learning: evidence from ClassStart application in Thailand. Behaviour \& Information Technology, 38(12), 1243-1258.

Wang, Y., Wu, M., \& Wang, H. (2009). Investigating the determinants and age and gender differences in the acceptance of mobile learning. British Journal of Educational Technology, 40(1), 92-118. 